\title{
The Case of Женитьба \\ The Two Versions of Musorgsky's Opera Fragment
}

\author{
Márta PAPP \\ Hungarian Musicological Society \\ Institute of Musicology \\ Táncsics Mihály u. 7, H-1014 Budapest, Hungary
}

(Received: September 2016; accepted: November 2016)

\begin{abstract}
The composer's two completed but very much differing versions of $B o$ ris Godunov still pose many serious questions to both performers and analysts alike. Few people know that Musorgsky also completely revised his operatic fragment The Marriage that immediately preceded Boris, and furthermore hardly a trace exists in musicological literature of the fact that The Child composed at that time, which later became the first item of the song cycle The Nursery (with the title of With Nurse), was also the subject of a revision. What connection there is between the versions of these three works and how Musorgsky's operatic style developed in 1868 are questions to which the present article seeks the answer.
\end{abstract}

Keywords: Musorgsky, The Marriage, Boris Godunov, The Nursery

\section{Research precedents}

However inappropriate this may seem in a scholarly publication, I would like to start with a personal story. In the autumn of 1978 János Bojti and I visited libraries, music and manuscript collections in Moscow and Leningrad to collect material for our Hungarian Musorgsky book. ${ }^{1}$ It proved terribly difficult to acquire copies of manuscripts, especially unpublished ones, and even if we succeeded, we had to sign a declaration that we would not use the full copy for publication, at most a small part of it. The only exception was the Glinka Museum in Moscow, which holds a number of music autographs by Musorgsky. The director welcomed us in

1. Published two decades later as Modeszt Muszorgszkij. Levelek, dokumentumok, emlékezések [Modest Musorgsky. Letters, documents, recollections]. Edited and translated by János Bojti and Márta Papp (Budapest: Kávé Kiadó, 1997). 
the friendliest manner, without any signs of mistrust, and as a farewell present without our asking for it - she gave us a beautifully bound, extra large photocopy of the single unpublished manuscript of their collection: the full first version of Musorgsky's opera fragment entitled The Marriage. The gesture was moving, but at that time I paid little heed to this fortunate acquisition. After all, the completed act of The Marriage was published in 1933 as part of the complete edition, and even though its editor Pavel Lamm had not been aware of the first version, an article published in Sovetskaya Muzika in 1964 already reported on the differences between the first version and the revised form. ${ }^{2}$ It was almost four decades later that I looked at the present from the Glinka Museum once again to carefully compare it with the published score and all relevant scholarly publications. The results were surprising. ${ }^{3}$

\section{The Marriage in the literature}

In the summer of 1868 Musorgsky began to set to music Gogol's comedy entitled The Marriage without using a libretto proper. After completing a single act he gave up the project, but his work acquired some historical reputation as one of the first attempts at a recitative-opera or "opéra dialogué." Even though the composition has been cited in most surveys of opera history and every $\mathrm{Mu}$ sorgsky monograph as a daring experiment to reflect human speech as faithfully as possible in the vocal melody and as a precedent to the leitmotif technique of Boris Godunov, the only study to deal with the work in any depth is Richard Taruskin's "Handel, Shakespeare and Musorgsky," first published in 1983. ${ }^{4}$ The eminent American scholar adumbrated the intellectual history of The Marriage, and argued that Dargomïzhsky's The Stone Guest had not been the sole source of inspiration for Musorgsky's completed act. The views of Georg Gottfried Gervinus, ${ }^{5}$ in particular his 1868 book entitled Händel und Shakespeare. Zur Ästhetik der Tonkunst directly influenced Musorgsky's attempt at expressing human emotions and states of mind not only through the meaning of words, but also by composing out the outward form of speech, its intonation, as he insisted in several

2. Ye. K. Antipova / Е. К. Антипова: “Два варианта »Женитьбы«” [Two variants of “The Marriage”], Sovetskaya Muzika 1964/3, 77-85.

3. Hereby I would like to express my gratitude to the former director of the Glinka Museum, Yekaterina Nikolayevna Alekseyeva.

4. Richard Taruskin, "Handel, Shakespeare and Musorgsky: The Sources and Limits of Russian Musical Realism," in idem, Musorgsky. Eight Essays and an Epilogue (Princeton, New Jersey: Princeton University Press, 1993), 71-95. First published in Studies in the History of Music, vol. 1: Music and Language (New York: Broude Brothers Limited, 1983), 247-268.

5. In his autobiography of 1880 Musorgsky mentions Gervinus as the discoverer of the exact musical laws of human speech. See The Musorgsky Reader. A Life of Modeste Petrovich Musorgsky in Letters and Documents, ed. and transl. Jay Leyda and Sergei Bertensson (New York: W. W. Norton, 1947), 419-420. 
of his letters written around this time. Taruskin described the speedy genesis of The Marriage only briefly, on the basis of the dates the composer provided for the four scenes; but he delivered a detailed analysis with musical illustrations of the extremely careful, rhythmically scrupulous vocal elaboration of Gogol's text, and characterized the orchestral background, i.e. the piano part, as minimal, mostly restricted to ironic commentary on the text. Taruskin made no mention of the fact that The Marriage had survived in two different autographs, i.e. in two authorial versions, similarly to Boris Godunov and a number of Musorgsky songs. He hinted at this state of affairs only in the first part of his later study on the two versions of Boris, published in $1984,{ }^{6}$ where he explored the issue of musical continuity in the orchestra and Musorgsky's peculiar leitmotif technique. Here Taruskin did refer to Ye. K. Antipova's article in Sovetskaya Muzika, quoted one of its music examples, and cited Antipova's view that the revision of The Marriage "affected the vocal parts hardly at all," whereas the identifying themes came to be multiplied in the accompaniment: "by using them Musorgsky sought to compensate for the 'formlessness' of his setting, in which the vocal lines are so much less structured than Dargomïzhsky's [The Stone Guest]."7 The latter statement about the identifying themes already partially reflects Taruskin's view, but his words on the two versions leave no doubt that he had no access to the autograph of the first version, therefore his conclusions are based exclusively on the article published in Sovetskaya Muzika.

However, the information provided by Antipova's article about the differences between the two autographs of The Marriage, kept in the Glinka Museum of Moscow and the Saltikov-Shchedrin Public Library of Leningrad (today Saltikov-Shchedrin National Library of Russia in St Petersburg), respectively, is scarce and superficial, to put it mildly. Regarding the provenance of the autograph in the Glinka Museum, the introduction quotes a 4 October 1940 letter by one Aleksey Sibiryakov, ${ }^{8}$ according to which the manuscript once belonged to the singer Anna Vorobyeva-Petrova, who, together with his husband, had been very close friends with Musorgsky. ${ }^{9}$ She gave the manuscript as a gift to his beloved nephew Iliodor Ivanovich Sibiryakov, from whom it came into the hands of his son Aleksandr Iliodorovich Sibiryakov, and then the latter's son, the writer of the letter. The Sibiryakov parents were operatic artists, their son a pianist, and they considered the Musorgsky manuscript (which had been identified as such in the Leningrad

6. Richard Taruskin, "Musorgsky vs. Musorgsky: The Versions of Boris Godunov," I-II, 19th-Century Music 8/2-3, (Autumn 1984 - Spring 1985), 91-118 and 245-272. Reprinted in his Musorgsky. Eight Essays and an Epilogue, 201-299.

7. Taruskin, "Musorgsky vs. Musorgsky," 103-105.

8. Antipova, “Два варианта," 77. While this is not documented, one assumes that the article only quotes an excerpt of Sibiryakov's letter. It is unclear who the recipient was, and the informal salutation ('Дорогая Оля') and thouing seems at odds with the official-looking signature ('Алексей Сибиряков') at the end of the letter.

9. In Antipova's view Musorgsky gave the autograph to Vorobyeva-Petrova when starting work on his Boris Godunov, but her basis for this assumption remains obscure. 
Conservatory in 1928) as a great treasure - this much do we learn from the passages quoted from the letter. Later the manuscript came in the hands of another artist and collector, Nikolay Pavlovich Smirnov-Sokolsky, until it was acquired in 1940 by the library of the Moscow Conservatory, wherefrom it was transferred to the Glinka Museum.

With all of that in mind Antipova observes that Musorgsky's dates on the Moscow and Leningrad manuscripts are identical, but fails to draw the obvious conclusion that (similarly to a number of other works by Musorgsky) the second version of The Marriage must have been dated back, and she makes no effort, either, to clarify the actual date of the revision. The title page of the Moscow manuscript, i.e. the first version, includes a brief list in Musorgsky's hand meant for the performers, which does not appear on the autograph of the second version, and consequently in the preface to Lamm's edition - this may have eluded Antipova's attention, or she may not have attributed any significance to it, even though it is of some interest. ${ }^{10}$ In Antipova's interpretation, the vocal parts of the two versions differ only in a few instances: her music examples demonstrate a few extended jumps in the vocal lines, and only in a single case the expansion of a recitative through articulating rests. She ignores the many instances where the bar lines are changed, therefore the accents fall on different beats. With respect to the piano part, Antipova observes the obvious fact that in the second manuscript, i.e. the revised version, ${ }^{11}$ it plays a much greater role in that it complements and enriches the characterization of the protagonists. In order to illustrate this point she quotes three excerpts from both manuscripts: the narrative of the friend named Kochkaryov about the approaching cohort of children (Scene 4), the instrumental theme associated with the storming in of Fyokla the matchmaker (Scene 2), and an utterance of the main hero, the old bachelor Podkolyosin (Scene 4), in the first version of which Musorgsky added in pencil "на ходах 1-й сцены" (i.e. the patchy chords of the piano should be completed by Podkolyosin's laziness motif in analogy of Scene 1, a plan the composer indeed realized in the revised version). It is this last significant and telling change that Taruskin also quoted from the article in Sovetskaya Muzika. ${ }^{12}$ Antipova also mentions, although without providing a music example, the bride's 'tender, sweet' theme, which returns in diverse versions in

10. This list of annotations for the performers is reproduced only by Aleksandra Orlova, although she incorrectly connects it to the second version; see Орлова, Труды и дни М. П. Мусоргского. Летопись жизни и творчества [Musorgsky's works and days: a biography in documents] (Moscow: Muzgiz, 1963), 157-158. The list is missing from Valentin Antipov's work list, which as a rule contains the most detailed descriptions of the autograph manuscripts; see Антипов: “Произведения Мусоргского по автогпафам и другим первоисточникам. Аннотированный указатель” in Наследие М. П. Мусоргского. Сборник материалов. [Musorgsky's legacy: a collection of materials] (Moscow: Muzika, 1989), 86.

11. The article refers to 'first' and 'second manuscripts' throughout, without using the expressions 'second version', 'revision' or 'revised version' - as if the author meant to downplay the significance of the revision also in her terminology.

12. Taruskin, "Musorgsky vs. Musorgsky," 104. 
the second manuscript, but she fails to notice that a variant of this theme is already associated with the girl in Scene 4 of the first version, and made its way into the earlier scenes of the revised version on this very basis. And, overall: apart from a reference to the memo about using Podkolyosin's laziness motive, the article does not even hint at the Moscow manuscript's 'work in progress' character, the cancellations in pencil, minor instrumental motifs that would turn into important themes in the second version. Nonetheless, it is only by studying these that the ravelling out of the revision of The Marriage can start, which allows us an insight into one of the crucial turning points in the development of Musorgsky's style.

\section{Work on The Marriage}

Musorgsky dated the fragment on the title page of the autograph first version, in the top right corner: "I began to write on Tuesday 11 June [18]68 in Petrograd. I completed the act on Tuesday 8 July [18]68 in the village Silovo of Tula Governorate."13 Each of the four scenes is dated after the double bar line, in vertical script: "20 June 68. in Petrograd" / "2 July 68. In the house at Silovo. M. Musorgsky" / "6 July 68. The house at Silovo. M. Musorgsky" / "8 July 68. The house at Silovo. M. Musorgsky." As mentioned above, the composer accurately transferred each of these dates to the autograph of the second version. On 2 January 1873 he gave the latter to Vladimir Stasov, on the occasion of his friend's birthday. The letter he attached to the present proves that, even five years later, after completing Boris Godunov, Musorgsky thought highly of his youthful work, the idea of which - as he writes "was suggested to me by Dargomïzhsky (as a joke) and by Cui (not as a joke)". ${ }^{14}$

According to his own dates, Musorgsky began to compose The Marriage at the beginning of June 1868 in Saint Petersburg (or, as he liked to refer to the Russian capital, Petrograd), and in late June continued his work on his brother's country estate, in a village house at Silovo. In his letters written from Silovo to his Saint Petersburg friends he gave very detailed accounts of his work and discussed in general the theoretical and practical problems of his 'opéra dialogué' experiment. Here I review the practical aspects of his compositional work, on the basis of Musorgsky's letters.

The first scene of The Marriage was completed in the capital, sitting besides the piano. The composer showed it, or parts of it, to Dargomïzhsky and Cui, and subsequently refined the score, on the basis of the advice he received, in his ru-

13. The dates cited here should be read according to the old Russian Julian calendar. In the $19^{\text {th }}$ century this ran 12 days early in comparison to the Gregorian calendar used in Europe.

14. Written to Vladimir Stasov on 2 January 1873. See The Musorgsky Reader, 204. 
ral solitude ${ }^{15}$ It was in Silovo that he decided to expand the first act from three to four scenes, and scenes 2, 3 and 4 were committed to paper with astonishing speed, in around one week and a half. Here Musorgsky composed without piano, a method that was absolutely new to him and made him feel insecure. "Now, contrary to my custom, I am composing the draft without a piano because there's no instrument here; I shall put everything in order in Peter[sburg]," he wrote to Cui on 3 July $1868 .{ }^{16}$ And on the same note to Rimsky-Korsakov on 15 August: "For the first time in my life I wrote without the aid of an instrument, that is, without verification of the composed work... But having received your and César's epistles, I was inflamed with a fever for order and I cleaned and brought order to what was composed..."17 The latter comment could potentially refer to the revision, but I am convinced that this 'ordering' involved the corrections he had made in the manuscript of the first version, and the true fair copy was prepared later in St Petersburg, at the piano, and implied serious fine-combing and rewriting. Musorgsky returned from Silovo to the capital on 20 August, and the 'private premiere' of the completed act of The Marriage was held on 24 September 1868 in the apartment of the Cuis. ${ }^{18}$ Subsequently it was also performed in other homes, where members of the Balakirev circle played music together on a regular basis. The pianist Nadezhda Purgold, later wife of Rimsky-Korsakov, recalled this as follows:

\begin{abstract}
When Musorgsky's Marriage was played at our home, A. S. [Dargomïzhsky] sang the role of Kochkaryov, roaring with laughter till the tears came to his eyes, and enchanted by the wit and expressiveness of this music. ${ }^{19}$ In the place where Kochkaryov says "these darling little head clerks, these sweet little rascals" A. S. was always obliged to stop, he was so overcome with laughter, and he said to me, 'You're playing some sort of symphony there, you're hindering my singing' (in the accompaniment at this point Musorgsky had some amusing curlicues). ${ }^{20}$
\end{abstract}

As to the date of revision, it is the last sentence that proves conclusive: the "amusing curlicues" that Dargomïzhsky referred to as "symphony" only appear in the piano part of the second version, whereas in the first version but a few chords accompany Kochkaryov's solo. Thus, Musorgsky must have revised and written

15. On 3 July 1868 he wrote to César Cui from Silovo: "Being guided by the remarks by you and by Dargom[ïzhsky] I have considerably simplified that which I showed you, and I have acquired for Podkolyosin a very fortunate orchestral phrase... Dargom seems fully satisfied with it...” The Musorgsky Reader, 107.

16. Ibid., 108.

17. Ibid., 119.

18. See Aleksandr Borodin's letter to his wife dated 26 September 1868. Ibid., 124.

19. The old Dargomïzhsky was so enthusiastic about The Marriage that he copied out Kochkaryov's part, which he sang at the private performances, and gave this manuscript to Musorgsky, who donated it to Vladimir Stasov when dedicating the work to him in 1873. See ibid., 124-125 and 203.

20. Ibid., 124. Nadezhda Rimskaya-Korsakova (Purgold) penned her recollections as late as 1913, but we have no reason to question the objectivity of her account about the performance of The Marriage. 
out The Marriage after returning to Saint Petersburg, between the end of August and 26 September 1868, and he thoroughly reconsidered the instrumental part, obviously with a piano at hand. After the performances in his friends' houses, however, he decided not to continue with his work on The Marriage, and as early as October 1868 he started to write Boris Godunov.

\section{The differences between the two versions}

When setting to music the first act of The Marriage, Musorgsky contracted Gogol's eleven brief scenes into four, preserving Gogol's text almost in its entirety. The first scene of the opera introduces the main hero Podkolyosin (baritone), a lazy, comfort-loving head clerk of Saint Petersburg, who is averse to any kind of change. Couching at home he is daydreaming about marriage, which he sees as a necessity, while he is juggling his servant Stepan (bass). In the second scene Fyokla the matchmaker (mezzo-soprano) pops in to describe the bride's personal virtues and the value of her dowry - God knows how many times Podkolyosin had already listened to her gabble. In Scene 3 enters Kochkaryov (tenor), Podkolyosin's ready-witted, hyperactive friend, who learns from Fyokla about Podkolyosin's plans and the identity of the bride, and flings out the matchmaker to take care of the matter himself. In Scene 4 Kochkaryov keeps describing the joys of marriage and children with such zeal that he eventually manages to convince Podkolyosin to come with him and visit the bride.

On the title page of the autograph first version, in the lower left corner, $\mathrm{Mu}$ sorgsky wrote a few important guidelines under the heading "For the performers". These are obviously not meant to be exhaustive; he may only have noted these for himself, so that he would not forget to call attention to them when preparing later private performances. ${ }^{21}$ The first point is of general relevance: "In this work one should strictly observe every sign that illuminates the mutual relationships of the

21. Исполнителям:

1. Строго выполнять все заметки в этом сочинении, уясняющие взаимные положении действующих, а равно и характер интонации.

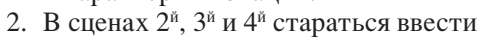
Подколесина несколько медленнее Фекли и Кочкарева, исключая следующих мест:

а) после слов Феклы: “седой волос и пр.”

б) при пуганьи Кочкаревым

в) слова: "пожалуй, едем"

г) последние слова Кочкарева: “да полно, еду"

3. Запомнить условные знаки для пауз:

$V=$ незначительная едва заметная остановка

$\curvearrowright$ = остановиться немножко долее.

М. Мусоргский 
characters, and at the same time the character of the intonation." The second point is already much more concrete:

In Scenes 2, 3 and 4 the materials of Podkolyosin are somewhat slower than the materials of Fyokla and Kochkaryov, except for the following places:

a) after Fyokla's words "grey hair, etc."

b) at Kochkaryov's threatening

c) at the words "please, let's go"

d) at Kochkaryov's last words: "stop it, I go"

The third point discusses the conventional and special signs for rests and breaks: the wedge-shaped sign indicates an "insignificant, barely noticeable stop," the fermata a "slightly longer stop." The composer's comments in both the second and the third points suggest that he meant the interpretation of this special work to be lively, flexible, and speech-like. In the dialogues, Podkolyosin's slow, slack personality should come to the fore also through tiny decelerations (not registered in the score) in comparison with Fyokla's and Kochkaryov's vehemence, except for those situations where the main character gets excited - according to Musorgsky's list, at the following places: (a) when the matchmaker tells him to his face as a final argument that his hair is turning grey, and he is still a bachelor (at the end of Scene 1), (b) when Kochkaryov, who had arrived unnoticed, scares him with a blatant joke (at the beginning of Scene 2), (c) when Podkolyosin first says "alright, let's go" and see the bride (around the middle of Scene 4), and (d) when, after several withdrawals, he indeed becomes resigned to depart (at the end of Scene 4). The slightly slower and faster tempi must of course be dictated by the pianist or the conductor of the would-be orchestra, whereas "barely noticeable and slightly longer" stops described in the third point should primarily be taken care of by the singers. The wedge-like sign appears in the vocal parts a dozen times; on one occasion it serves slightly to prolong a quaver rest; in all other cases Musorgsky uses it as a specific musical punctuation mark to separate a word of the sung speech. The frequently used fermatas mostly prolong rests in both the vocal and the piano parts, but a fermata over the bar line is not uncommon, either, to momentarily bring the musical process to a halt and accentuate the beginning of the new bar. Musorgsky did not transfer this list of performing instructions into the revised version of The Marriage; instead, he indicated the slight tempo differences between the music for Podkolyosin, Fyokla and Kochkaryov through specific inscriptions: Медленно [Slowly] or Медленнее [More slowly] - Скорее [Faster]. Occasionally he makes use of the wedge-like sign in the second version 
Example 1a The Marriage, 1st version, end of Scene 1

Text: Hm... yes! This case... sure enough!.. bad job!..

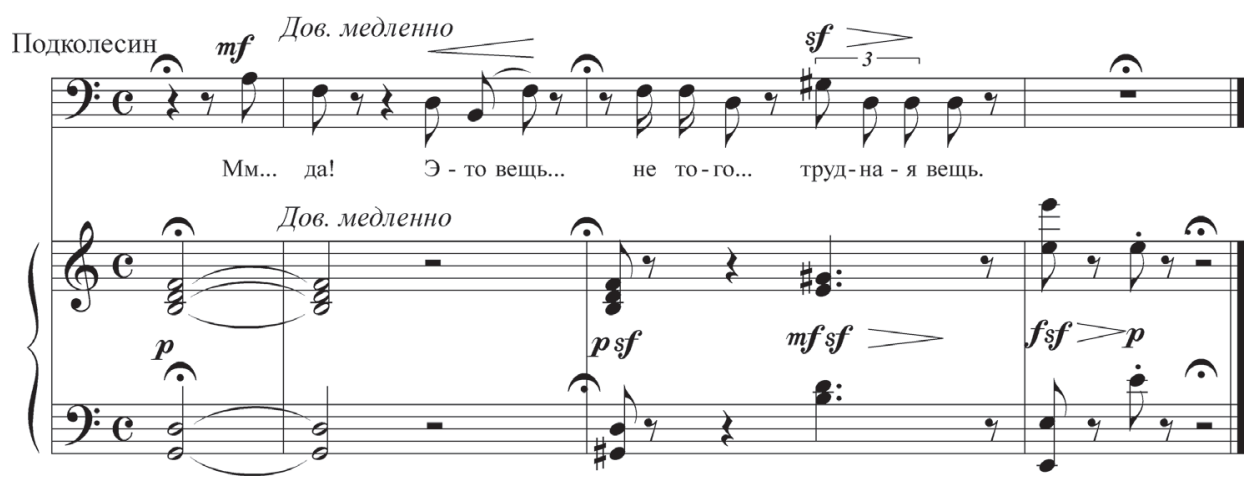

EXAmple 1b The Marriage, 2nd version, end of Scene 1

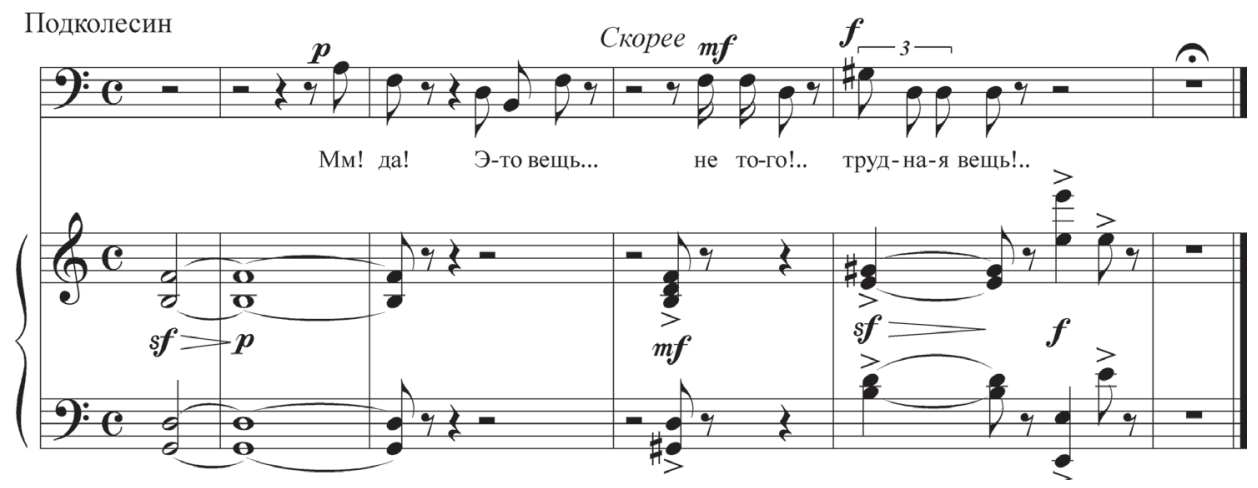

as well, ${ }^{22}$ but the stops with fermata are notated in a different manner: through inserting rests, augmenting or expanding bars, as shown in Example $1 a-b$.

In the first version the tardiness of Podkolyosin's rumination is emphasized through rests, fermatas and written instructions (Дов[ольно] медленно [Rather slowly]), in the second version the protagonist appears to overcome his sluggishness with respect to both dynamics and tempo; his last remark is accelerated (Скореe [Faster]), and the accentuated and strident $e$ 's, with which the piano concludes, already prepare Scene 2, the A-major arrival of the matchmaker. In this case, however, the acceleration is preceded by a longer rest, and so "bad job" is

22. In Lamm's complete edition the volume The Marriage contains only two such wedge signs (4 bars before figure 56 and 4 bars before figure 64), without any further explanation. It is possible, nevertheless, that the autograph of the final version (which I could not study) includes more of these. One of Antipova's music examples copied from this source also includes one, see Antipova, “Два варианта,” 78, Example 2. 
uttered only at the beginning of the next bar, thereby gaining greater accent than in the first version.

In general, changes in barring constitute a characteristic difference between the two versions of The Marriage. In an effort to precisely and effectively reflect on the prose text of Gogol's comedy, the composer felt inclined to alter the original bar structure of the vocal parts. In most cases the series of notes remained (or seems to have remained) the same, but it makes great difference for the performer - and through him or her also for the listener - which word receives greater accent, i.e. comes at the beginning of the bar. The tendency in these changes is interesting: in the first version the distribution of bars is primarily determined by the grammatical and syntactical structure of the text, whereas in the second version the prosody is more important, i.e. the sentence or phrase does not necessarily start on the first beat of the bar, but the word meant to receive an emphasis appears at the beginning of the bar. Examples $2 a-b$ and $3 a-b$ illuminate these differences.

Example 2a The Marriage, 1st version, Scene 1, bars 59-60

Text: It is possible that he said:

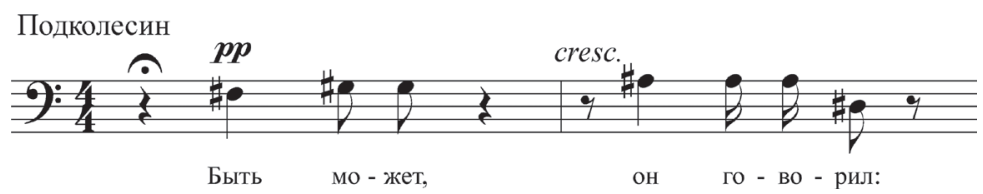

ExAmple 2b The Marriage, 2nd version, Scene 1, bars 61-62

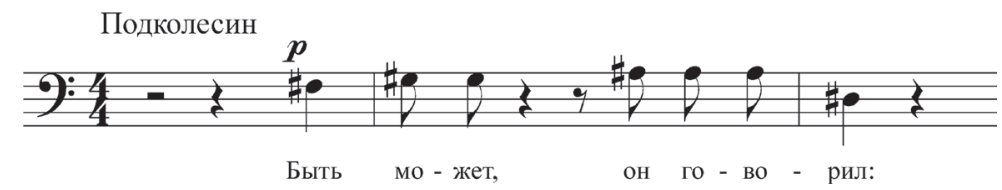

Example $3 a-b$ presents Fyokla's response to Podkolyosin's self-conceited remark that he is justified to have the best possible bride, since he is a court councillor, but the matchmaker snaps him up by pointing out that another court councillor also visited the girl, only to be rejected. The notation in the first version stresses the phrase "did not please"; in the second version "court councillor" and "was rejected" are also emphasized, making the whole sentence somewhat more articulate and therefore cheeky. Elsewhere Musorgsky prescribes a different bar structure or a change of meter to separate the participants of a dialogue, arguably to ensure a more articulated performance (see Examples $4 a-b$ ).

These are tiny differences that testify for the composer's struggle for rendering the speech in music as perfectly as possible. In Examples $5 a-b$ the change in bar structure implies some changes in the instrumental part as well. 
ExAmple 3a The Marriage, 1st version, Scene 2, bars 85-88

Text: How would I not understand? We also had a court councillor here, and he was rejected: he did not please!

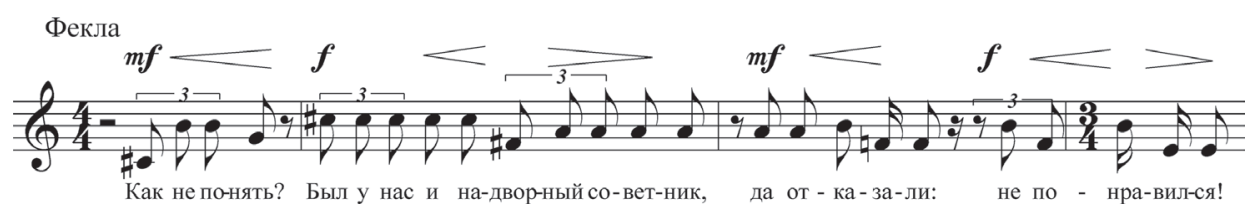

Example 3b The Marriage, 2nd version, Scene 2, bars 107-111

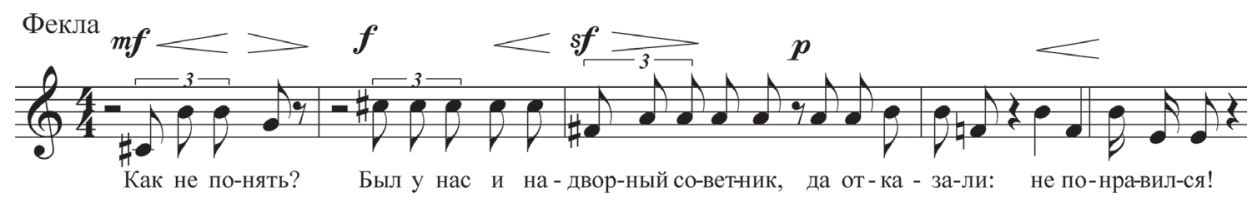

ExAmPLE 4a The Marriage, 1st version, Scene 1, bars 32-33

Text: Has the matchmaker not come? - She hasn't.
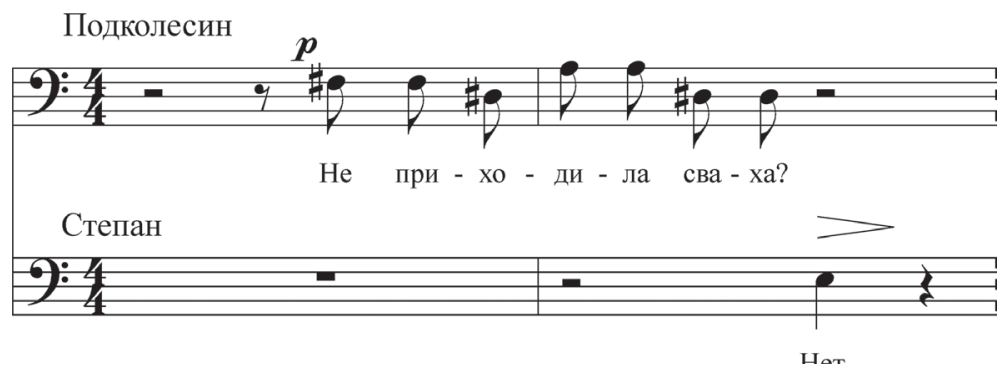

Example 4b The Marriage, 2nd version, Scene 1, bars 33-35

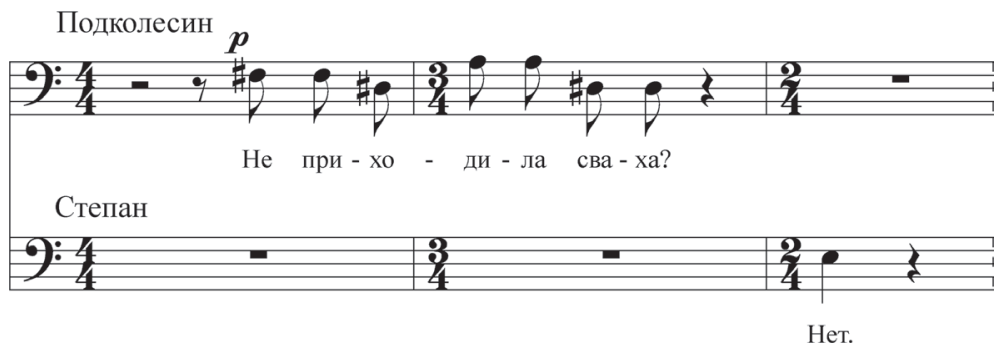


EXAmple 5a The Marriage, 1st version, Scene 2, bars 90-91

Text: either he says no word, or he is lying!

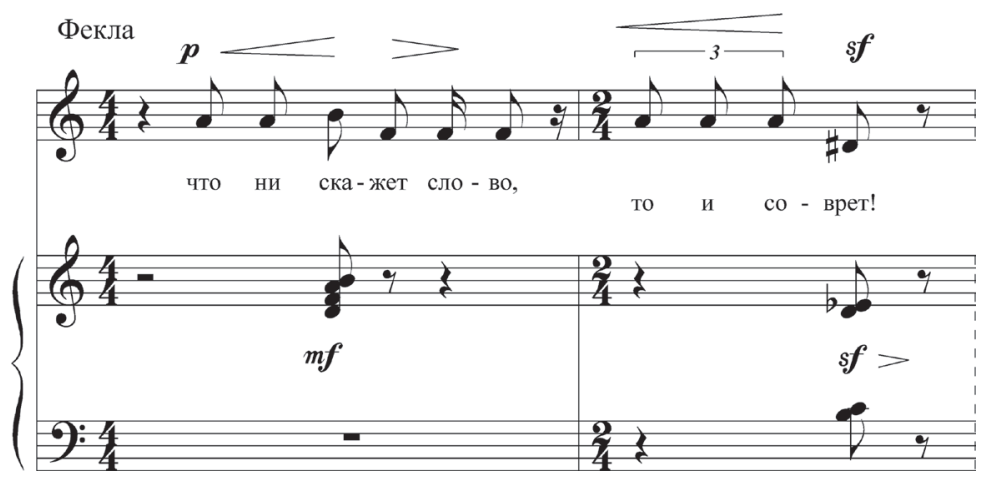

EXAMPLE 5b The Marriage, 2nd version, Scene 2, bars 113-115

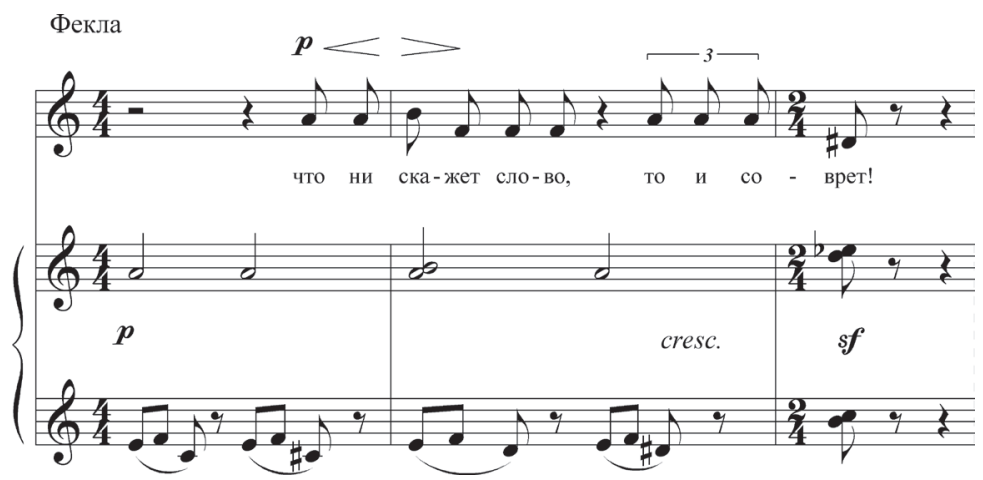

Besides refining the diction of the recitatives, Musorgsky's revision was primarily aimed at enriching the piano part of The Marriage. In this regard Scene 1 was changed the least, since this was written in Saint Petersburg, sitting at the instrument. It includes one of the most important leitmotifs of the opera, Podkolyosin's laziness theme, which opens the entire work; its variants interweave the whole act, carefully reflecting on the different gradations of the hero's tardiness, on imagined and real dangers, as well as psychological effects, on his getting out of the comfortable groove. ${ }^{23}$ The other leitmotif that appears already in the first version and returns several times in all four scenes is the theme of the proposing, which Musorgsky, as is revealed in a letter he wrote from Silovo, had shown to Dargomïzhsky in Saint Petersburg:

23. In the case of Podkolyosin's laziness theme and other leitmotifs discussed below I intentionally use two terms, 'theme' and 'motif', since each of these appear both in longer, 'theme-like' forms and as short, 'motif-like' signals of a mere two or three notes. 
I have acquired for Podkolyosin a very fortunate orchestral phrase, which can be used by me to the best advantage for the scene of the marriage proposal:

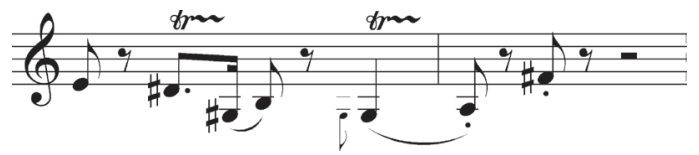

Dargom[ïzhsky] seems fully satisfied with it, and it makes its appearance for the first time in the conversation with Stepan at the words: "Well, and didn't he ask" and so on... about the marriage, in a word. This, as you can see, is a fragment of the little theme which appears fully at the moment of the formal proposal in the third act, when Podkolyosin has already decided to get married. On it can very well be constructed the stupid embarrassment of Podkolyosin. ${ }^{24}$

There is of course no way of knowing what the full theme would have looked like in Act 3, but we can trace its effective use in both versions of Act 1. In the process of revision the use of the proposal theme barely changed; the only conspicuous difference occurs at the very end of the act: in the first version the theme is undulating at length, and the laziness theme is also interwoven into it, demonstrating the hesitance and eventually the forced getting under way of Podkolyosin, whereas in the second version the scene comes to an end after a single-bar flash (see Examples $6 a-b$ ).

Besides the themes associated with laziness and the proposal, respectively, the third recurring theme of Scene 1 is related to the servant Stepan, accompanying his clumsy entrance, exit and reluctant answers; this was also taken over unchanged into the second version. In Scene 2 three important new instrumental themes appear in the piano part. The first one is the introduction itself: a sprightly $2 \times 2$ bar theme with triplet-sextuplet rhythm, in which minor, Lydian, and major modes alternate, associated with the rushing in of the matchmaker - this will serve as the basis for Fyokla's narrative about the bride's dowry. The second theme, which is directly connected to the introduction, is Fyokla's personal leitmotif - a tiny melody in folk character featuring a grotesque affix with characteristic rhythm. Each element of this theme will subsequently be used in combination as well as separately, and unmistakably pictures the character of the matchmaker (Example 7).

The third new theme characterizes the bride, and is occasionally combined with Fyokla's motif, since she is depicting the girl's beauty for Podkolyosin. In the music of The Marriage, which cannot be described as melodious, this is as good as the only 'sweet melody', a variant of which Musorgsky emphatically evokes in Scene 4, when Kochkaryov seeks to seduce and stimulate Podkolyosin by depict- 
Example 6a The Marriage, 1st version, end of Scene 4
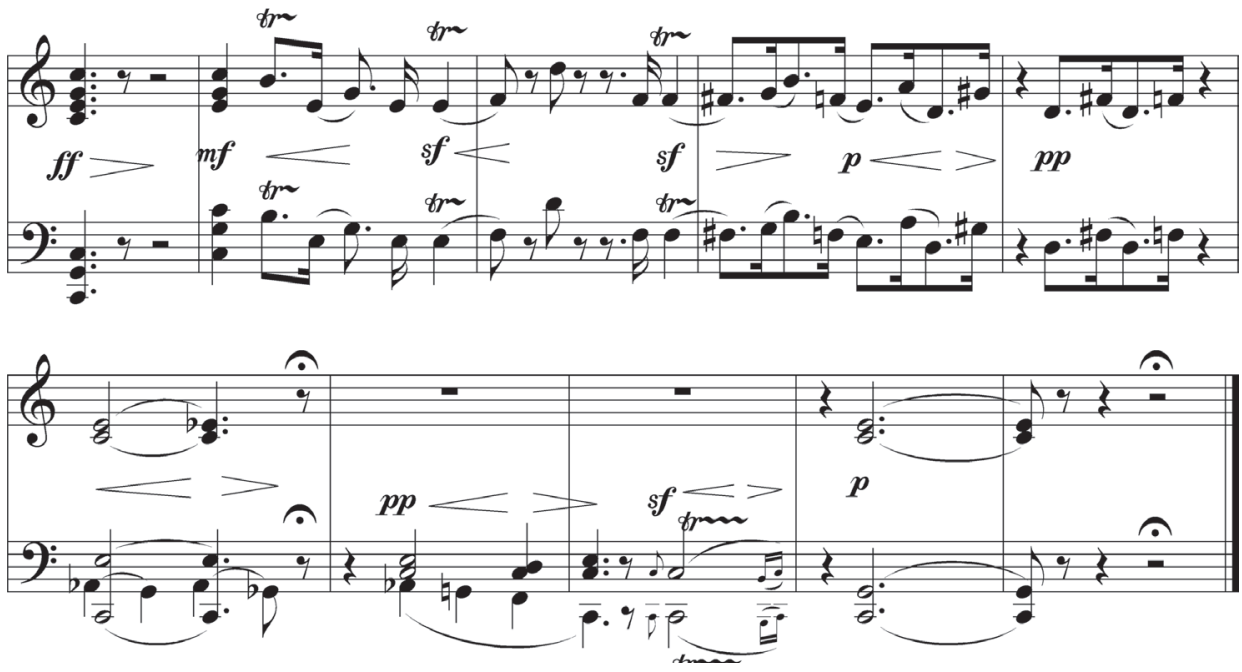

Example 6b The Marriage, 2nd version, end of Scene 4

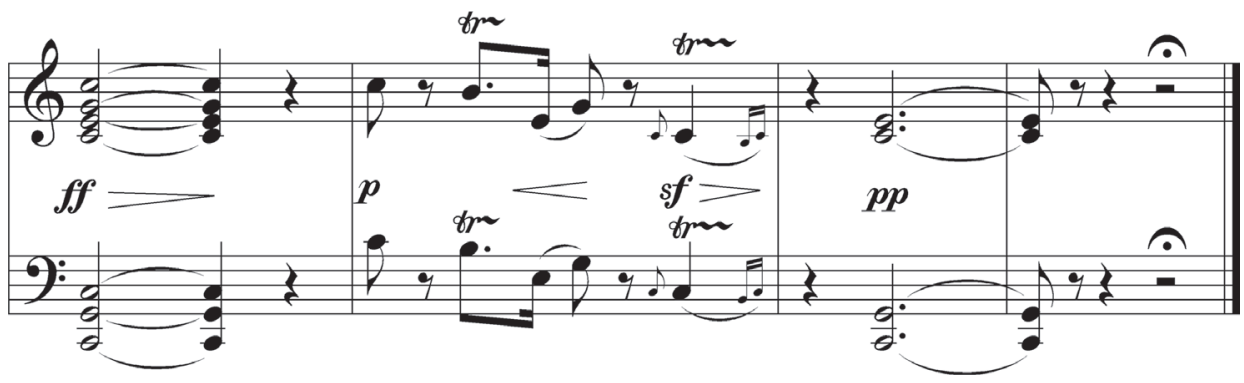

EXAMPLE 7 The Marriage, 2nd version, Scene 2, bars 5-7

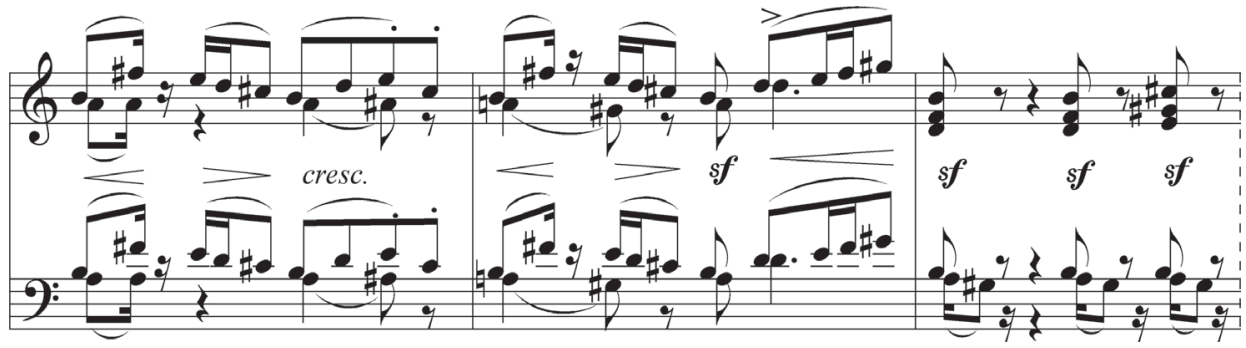


ing the girl's beauty and amiability, and the theme snugs itself in the main hero's brain more and more (see Examples $8 a-b$ ).

However, the girl's theme - as can be seen in Example 8 - is not entirely new: it was born in the closing scene of the first version, and during the revision $\mathrm{Mu}$ sorgsky inserted a variant of this into Scene 2, for Fyokla's words. The themes of Fyokla and Kochkaryov came into being in a similar process. In Scene 2 of the first version, which is the 'grand scene' of the matchmaker, Fyokla's characteristic

EXAMPLE 8a The Marriage, 2nd version, Scene 2, bars 81-85

Text: Like honey! Snow-white, rose-cheeked, like blood with milk! It is so sweet that it cannot be told.
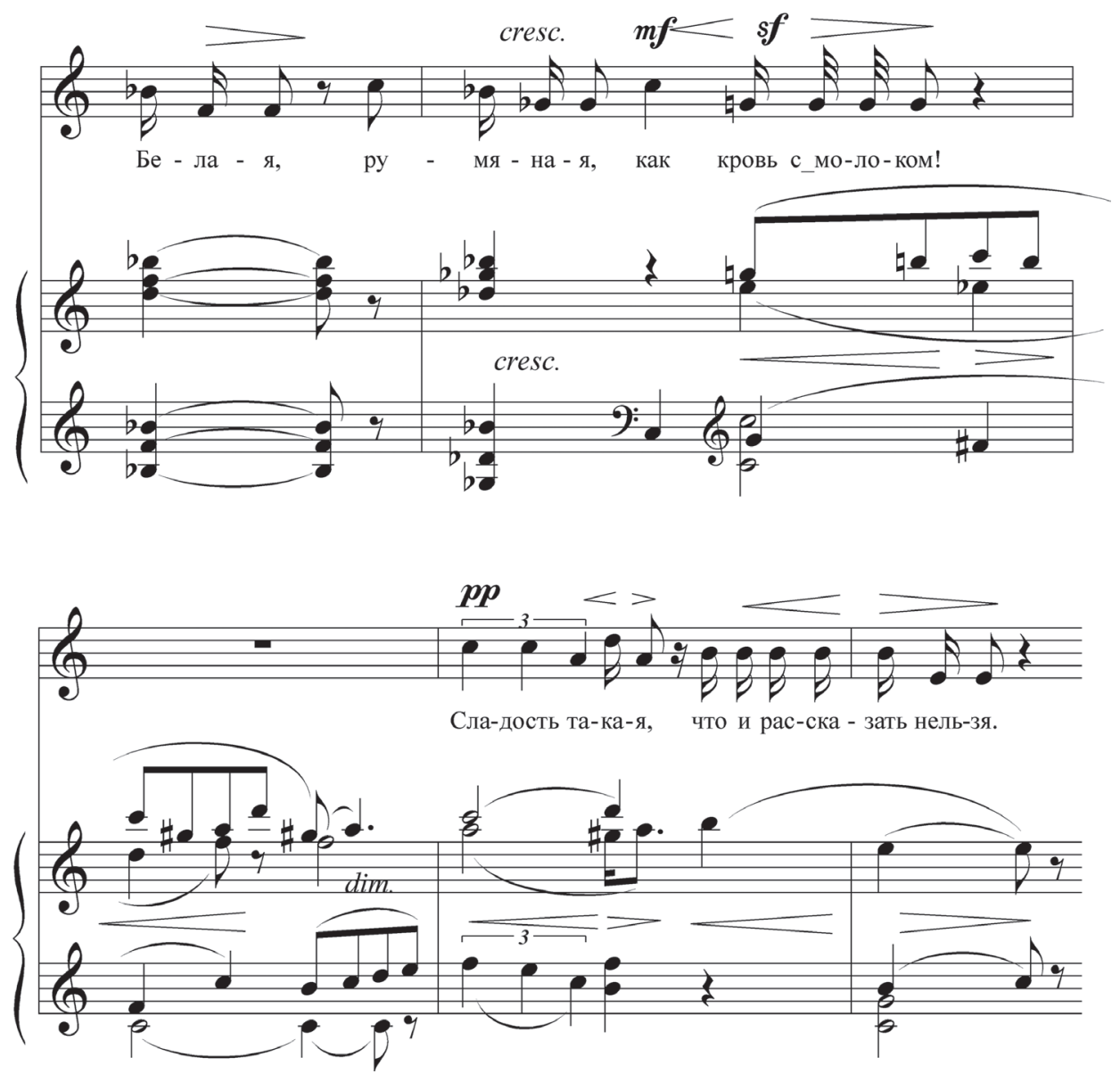
ExAmple 8b The Marriage, 1st version, Scene 4, bars 41-45

Text: [a pretty little woman sits next to you!] And with her tiny hand... you... and with her tiny hand... you
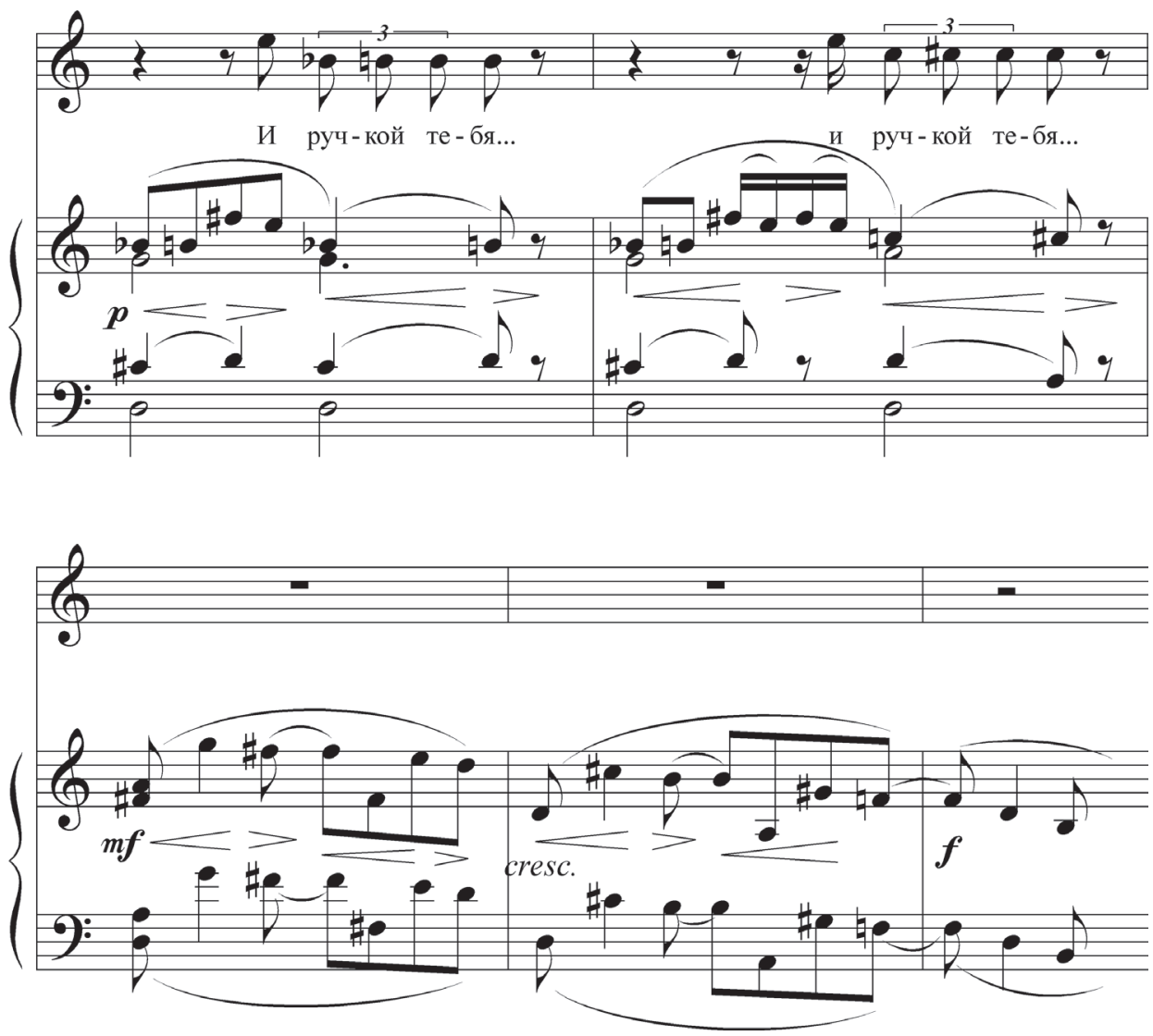

leitmotif is as yet fully absent (see Example 7). In Scene 3 its intensive presence is only hinted through rather neutral scalewise motion in triplets, which Musorgsky crossed out in pencil in the next phase of the compositional process, probably yet in Silovo. However, in two instances this triplet passage is connected to the motivic cell with characteristic rhythm, which the revision turned into the complete theme, integrating it into scenes 2 and 3. In the first version one finds several pages crossed out in pencil also in Fyokla's dowry narrative of Scene $2,{ }^{25}$ which is accompanied here by patches of chords, tiny and disconnected motifs, whereas in the second version by a continuous triplet motion derived from the introduction. The hyperactive Kochkaryov is associated with a peculiar rhythmic figure depicting his 
continuous movements, tosses and turns, fussiness. In the first version this figure appears only for a few measures in Scene 4, when Kochkaryov sets out to persuade his friend to act (Example 9); in the revision Musorgsky used it as a starting point for illustrating Kochkaryov's activity already in Scene 3, and made ample use of the motif also in Scene 4 in the instrumental accompaniment of Kochkaryov's narrative about the 'little head clerks', i.e. the would-be cohort of children, which made Dargomïzhsky laugh so hard at the private performances mentioned above.

EXAMPLE 9 The Marriage, 1st version, Scene 4, bars 29-30

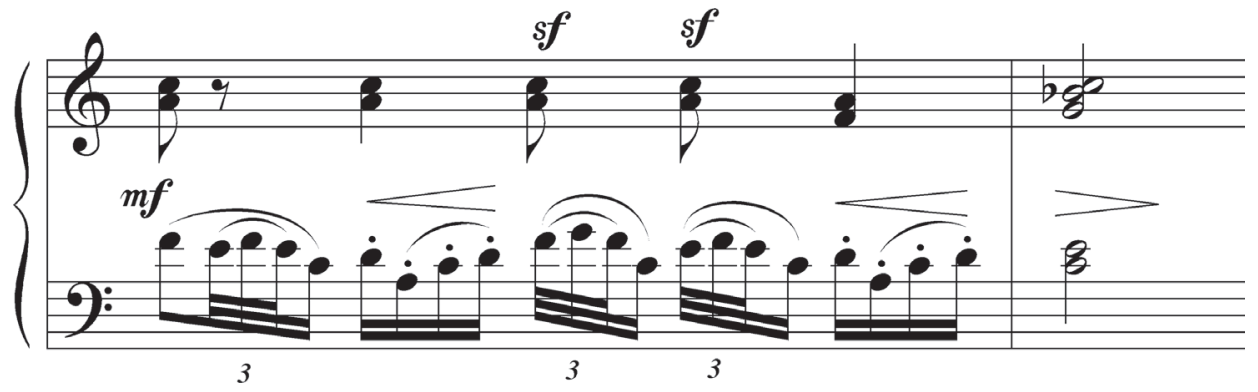

As regards musical character, each motif of The Marriage precisely and humorously characterizes the person in question, as well as the actual situation. The question remains how they fit into the musical process, i.e. whether they produce a continuous musical texture at all. The answer is negative: not even in the revised version. At the very beginning of Scene 1 one perceives that the composer sought to construct an instrumental process out of Podkolyosin's theme: the initially C-major theme of six bars, which Musorgsky keeps changing and developing, returns in $\mathrm{G}$ major (bars 13ff), then starts on $\mathrm{F}$ after the first and second dialogues with Stepan (from bars 116 and 176, respectively). The returns of the basic theme outline some sort of constructive overall form, even though the texture becomes more and more fragmented as the scene proceeds, and Stepan's theme functions as a mere 'calling card' before and in between the recitative dialogues. In the later scenes there is no coherently developed or repeated instrumental part, nor does an architectonic form emerge. The new or reworked leitmotifs initiate a process by way of repetition or variation in the extensive dowry narrative based on the instrumental introduction to Fyokla's entry (Scene 2, bars 36-76) and Kochkaryov's solo about the coming cohort of children (Scene 4, bars 119-132). Nonetheless, the vocal part remains recitative throughout, even in the above-mentioned solos; the leitmotifs do not appear in the sung part at all. After the private performances Musorgsky may have realized that all of this will not amount to a proper opera, but in his subsequent, no less daring and innovative, works - Boris Godunov and the cycle The Nursery - he successfully made use of the kind of recitative and leitmotif techniques he experimented with in The Marriage. 


\section{Changes in Musorgsky's style from 1868 to 1870 The Child / The Marriage / Boris Godunov / The Nursery}

Few scholars are aware that the first song of the cycle The Nursery has also survived in two forms. According to the date on the autograph, Musorgsky completed the first version on 26 April 1868, i.e. before composing The Marriage; at this stage the song's title was Дитл [The Child]. Later its autograph came to the Public Library of Leningrad (today Saltikov-Shchedrin National Library of Russia in Saint Petersburg), bound together with the manuscript of Eremushka's Lullaby. The two works were dedicated to "Aleksandr Sergeyevich Dargomïzhsky, great teacher of musical truth" on 4 May 1868. It is eminently possible that, when Dargomïzhsky received Musorgsky's manuscript, he carefully studied the vocal melody of The Child, which turns spoken speech into music with astonishing precision, ${ }^{26}$ and during their conversations about prosody suggested his young friend - whether in joke or not - to try to compose an opera on the basis of literary prose, for example Gogol's amusing The Marriage. Musorgsky followed the advice, but after completing and scrupulously revising the piano version of Act 1 of his "musico-dramatic experiment in prose", 27 he abandoned this work, and immediately started to set to music with enormous élan Pushkin's Boris Godunov. From October 1868 to December 1869 he completed his "musical drama in four parts and 7 scenes," 28 i.e. the first version of Boris. In 1870 Musorgsky also returned to The Child he dedicated to Dargomïzhsky; he revised the song and provided it with a new title (With Nurse), and by adding four more thematic songs he completed the cycle The Nursery by December $1870 .{ }^{29}$

On the one hand, The Child and With Nurse (i.e. the two versions of the first song of The Nursery) are almost identical; on the other hand, they are very different. The first version is 46 bars long, the second 53, and both include 27 changes in meter. Apart from minor differences in rhythm, the vocal and the piano parts are almost the same, but the distribution of bars is completely different. In the first version the bars and the changes of meter are determined by the grammatical structure of the text, while in the second prosody plays a more decisive role: it is the accented syllables that appear on the first beat of the bar. ${ }^{30}$ As we have seen, Musorgsky experimented with this highly differentiated musical rendering of spo-

26. As with all other songs, the text of The Nursery is by Musorgsky.

27. Musorgsky described the genre of The Marriage as "Опыт драматической музыки в прозе" [Musico-dramatic experiment in prose] in both autograph manuscripts, which also provide the subtitle "Совершенно невероятное событие в трех действиях" [Perfectly implausible story in three acts].

28. The composer described his Boris Godunov as a "Музыкальное представление в четырех частях и 7 картинах".

29. The seven-part cycle known today was compiled retrospectively from the five pieces of the original The Nursery and two songs under the title At the Dacha. The autograph of The Nursery is kept in the Glinka Museum in Moscow, that of At the Dacha in the Saltikov-Shchedrin National Library of Russia in Saint Petersburg.

30. See Petra Weber-Bockholdt, Die Lieder Mussorgskijs (München: Wilhelm Fink Verlag, 1982), 153155, and also Márta Papp: Muszorgszkij dalai [Musorgsky's songs] (Budapest: Editio Musica Budapest, 2015), $170-171$. 
ken speech in The Marriage, and while revising the fragmentary act he improved this style of writing focused on prosody, on the basis of which he went on to give the first song of The Nursery a new form as well. And just as Ye. K. Antipova paid no attention to the differences between the vocal parts when comparing the two versions of The Marriage, so did Pavel Lamm ignore the first version of the first song of The Nursery when publishing the Musorgsky complete edition, whereas he included the first version in several cases where Musorgsky's revision was less thorough. The original vocal part of The Child was first published by a German scholar, Petra Weber-Bockholdt. ${ }^{31}$

When composing the great work 'in between' - the first version of Boris Godunov - Musorgsky obviously built on his experiences with The Marriage, both positive and negative. If we ask what it was that the first version of Boris directly inherited from The Marriage, we first notice an outward means: in neither works did the composer use a key signature, thereby demonstrating the free transit from one tonality to others. ${ }^{32}$ A more important aspect is the thorough elaboration of the vocal parts as reflections of speech, which Boris has transferred to a pioneering new type of scene, the choral recitatives as well. Nevertheless, in most of the lengthy recitative scenes of Boris Godunov the vocal line is supported by instrumental parts, as opposed to the 'dry' recitatives of The Marriage, accompanied by mere patches of chord.

Yet another remarkable aspect of this 'heritage' is a special technique, the sequential repetition and variation of a characteristic motivic cell. Musorgsky experimented with this in two sections of the second version of The Marriage - the solos by Fyokla and Kochkaryov, respectively - and went on to use it as a means to ensure the coherence of longer scenes in Boris. A case in point is the characteristic semiquaver motif associated with the policeman who is taking action and giving commands in the first scene, set before the Novodevichy Monastery; this appears already in the accompaniment of the prelude, clatters in the people's scene in between the two praying choruses as well as the recapitulation of the chorus, returns in the next scene during the chorus's hailing at the Coronation, then once again with the border guards at the inn. Its variant also resurfaces in the St. Basil scene, and a more remote variant gets repeated when the doorman reports to the Tsar in the Terem scene (see Examples $10 a-b$ ).

Pimen's writing theme (Cell scene), the semiquaver sextuplet theme repeated during the monologue of the Tsarevich looking at the map (1st version, Terem scene, bars 12-34) or the rather characterless sequential semiquaver motif that

31. Weber-Bockholdt provides the voice part of The Child in her own notation, since she was unable to acquire a copy of the manuscript kept in the Public Library of Leningrad. See Weber-Bockholdt, Die Lieder Mussorgskijs, 153.

32. When revising Boris, Musorgsky already entered the accidentals in the manuscript, obviously in order to practically facilitate the work of the performers. 
Example 10a Boris Godunov, Scene 1, 3rd bar after figure 4

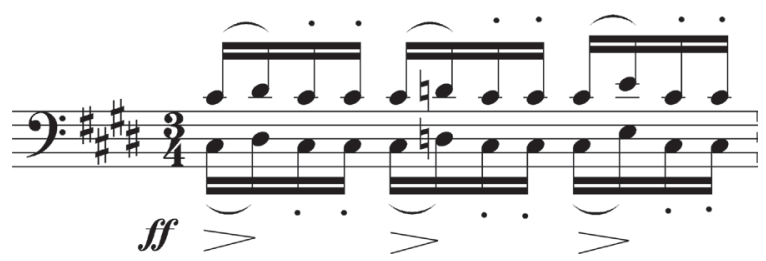

Example 10b Boris Godunov, Terem scene, 2nd and 3rd bars after figure 57

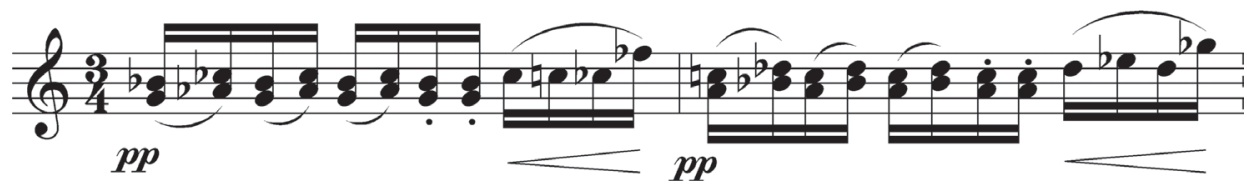

accompanies Shchelkalov's solo in the Death scene, all have a similar connecting power. That this may still not be the most effective means to create coherence was recognized by the composer by the time he completed the revised version of Boris: in the Cell Scene he radically abbreviated the recitative passages based on the writing motif, in the Terem scene Fyodor was given different music, and in the Death scene Musorgsky cut Shchelkalov's solo altogether. Only the most striking policeman motif remained unchanged, even in the almost completely rewritten Terem scene (see Example 10b).

The arguably most important 'operatic' heritage of The Marriage is the network woven out of characteristic motifs and themes brilliantly adapted to each character and situation. In the first version of Boris one finds more than a dozen such leitmotifs; the majority of them has survived in the revised version, even if occurring less frequently. Their effect is strong and direct: the listener recognizes the themes of Pimen's chronicle writing, Grigory's grand idea of usurping upon the power of the Tsar or Boris's madness, etc. just as naturally as the characteristic leitmotifs of Wagner's Ring. What is new, however, about Boris Godunov's leitmotifs in comparison to The Marriage, is the instrumental and vocal use of these themes, as well as their development, which also serves as a means of ensuring musical continuity. In Boris the instrumental and vocal use gains dramaturgical significance - the best-known example being Grigory's theme, which occurs to the young monk as 'lurking' in the orchestra and gets announced vocally by Shuysky; this has a devastating effect on the Tsar stung by his conscience. In the first version of Boris Musorgsky used the Grigory theme too generously, basing the entire second part of the Terem scene on its repetition and development. In the revised version the composer improved this section by finding new themes for Shuysky's Uglich narrative and Boris's visioning. It is the Inn scene that comes closest to The Marriage in both character and technique; here the variants of the 
Grigory theme typify the bodily and spiritual motions of the adventurous young fugitive just as the diverse occurrences of the leitmotifs of Podkolyosin, Kochkaryov or Fyokla, respectively, characterize the figures in the earlier fragment. (Varlaam's distinctively gross motif could even belong to the comic opera based on Gogol's story.) Nonetheless, the difference in musical modelling makes itself felt here as well: even though Boris's Inn scene proceeds rather fragmentarily in recitative set to a prose text, the vocal part is articulated by closed forms (Varlaam's song about the siege of Kazan, as well as the solo he sings while getting drunk, both in variation form) that organically integrate the leitmotifs (Varlaam's theme, for instance, is turned into an accompanying figure in the Song about Kazan, see Examples $11 a-b)$.

Example 11a Boris Godunov, Inn scene, 4th bar after figure 15

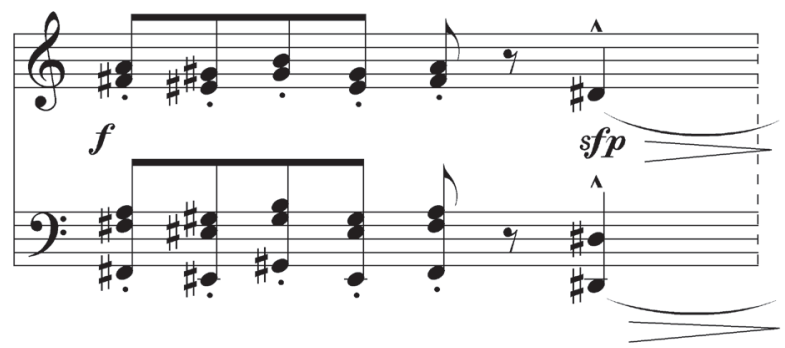

EXAmPLE 11b Boris Godunov, Inn scene, bars 3-5 after figure 19

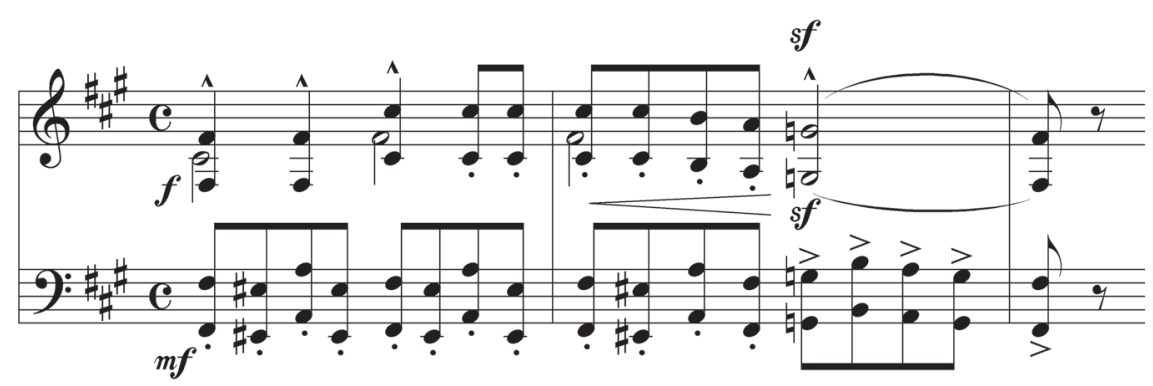

The changes that occurred in Musorgsky's style before, during and after composing The Marriage are flighty and quickly overshot phases of the composer's continuous quest for perfection. In the revised and new sections of Boris Godunov, later in Khovanshchina and Sorochintsy Fair, one observes new and new faces of his operatic construction. Nevertheless, it seems worthwhile to offer snapshots of the revision of individual works, among them the fragment The Marriage, which may shed light on important aspects of this constant change. 